\title{
Effect of Nature Walks on Depression and Anxiety: A Systematic Review
}

\author{
Yasuhiro Kotera $^{1, *(\mathbb{D}}$, Melinda Lyons ${ }^{1}\left(\mathbb{D}\right.$, Katia Correa Vione $^{1}(\mathbb{D})$ and Briony Norton ${ }^{2} \mathbb{D}$ \\ 1 Human Sciences Research Centre, University of Derby, Derby DE22 1GB, UK; m.lyons@derby.ac.uk (M.L.); \\ k.vione@derby.ac.uk (K.C.V.) \\ 2 Environmental Sustainability Research Centre, University of Derby, Derby DE22 1GB, UK; \\ b.norton@derby.ac.uk \\ * Correspondence: y.kotera@derby.ac.uk
}

Citation: Kotera, Y.; Lyons, M.; Vione, K.C.; Norton, B. Effect of Nature Walks on Depression and Anxiety: A Systematic Review. Sustainability 2021, 13, 4015. https://doi.org/10.3390/su13074015

Academic Editor: Takahide Kagawa

Received: 5 March 2021

Accepted: 2 April 2021

Published: 4 April 2021

Publisher's Note: MDPI stays neutral with regard to jurisdictional claims in published maps and institutional affiliations.

Copyright: (c) 2021 by the authors. Licensee MDPI, Basel, Switzerland. This article is an open access article distributed under the terms and conditions of the Creative Commons Attribution (CC BY) license (https:/ / creativecommons.org/licenses/by/ $4.0 /)$.

\begin{abstract}
The benefits of nature for our health have been an increasing research focus in recent years. In the context of a global increase in mental health diagnoses, the potential health benefits of nature have attracted attention. One practical nature treatment is to walk in nature. However, evidence for this practice on mental health has not been comprehensively appraised to date. This systematic review synthesized the effects of nature walks for depression and anxiety, and evaluated the methodological rigor of studies. Academic databases including ProQuest, PsycINFO, Science Direct, and Google Scholar were utilized to identify eligible articles, which were examined using the Newcastle-Ottawa Scale. Of 385 articles initially retrieved, 12 studies met all the eligibility criteria (nine pre-post within-subject studies, two quasi-experimental studies, and one experimental betweensubjects study). These studies demonstrated that nature walks were effective for state anxiety but not generalized anxiety and the effects for depression were inconsistent. Findings indicate that nature walks may be effective for mental health, especially for reducing state anxiety. However, the quality of the included studies varied, and sample sizes were small, suggesting a need for more rigorous and large-scale research.
\end{abstract}

Keywords: nature walk; state anxiety; PRISMA; nature-based intervention; systematic review

\section{Introduction}

In recent years, there has been increasing interest in the psychological and physiological benefits for individuals of spending time in nature [1]. Some of this interest is likely to have been motivated by acknowledging the damage from harmful human activities on our planet's fragile ecosystems and a keenness to attempt to reverse the harm [2] as well as from individual experiences of the simple benefits of enjoying time outside [3]. Spending time in nature and feeling connected to nature have positive impacts on people's mental health and wellbeing [1]. There is evidence that undertaking physical activity in nature can provide benefits above and beyond the benefits from the physical activity, through an increased connection to nature. The scope of physical activities examined embraces activities from the extremes of "free solo" climbing and kayaking [4] to less strenuous activities such as bird-watching or watching nature documentaries on TV [5] and the most popular "middle-ground" activities involving spending time in nature without strenuous activity including walking in nature. Nature-based interventions are potentially cost-effective treatments [6] that can provide multiple benefits [7] and are potentially accessible to a range of people providing there is adequate provision of public greenspace [8]. Forest bathing (shinrin-yoku) has received particular attention because it is often free and more accessible than established health interventions [9]. Other nature-based interventions, including walking in nature, have been demonstrated to have positive wellbeing impacts, including reducing stress levels [10]. Likewise, conducting a nature walk in a group reduced stress from stressful life events [11]. However, as for any therapy, there is still a need 
to understand how health benefits manifest before nature-based activities could be utilized in practice [12]. A substantial increase in the research base is required before nature-based activities can be prescribed alongside established therapies [9].

There is an urgent need for effective and cost-effective treatments for mental health conditions [13]. Mental health is a global and growing health challenge. In 2017, an estimated 792 million people were affected by mental health issues worldwide [14]. Since then, the COVID-19 pandemic and associated widespread socio-economic changes are leading to a mental health crisis globally [15]. Of the conditions assessed in 2017, anxiety and depression were the most prolific disorders reported, affecting 284 million and 264 million people, respectively [14]. Both of these conditions have increased prevalence during the COVID-19 pandemic [16,17].

Anxiety encompasses a range of disorders including Generalized Anxiety Disorder, Panic Disorders, and Social Anxiety Disorders. These disorders can hinder a person's ability to function normally, impacting job and academic performance, and personal relationships [18]. During the COVID-19 pandemic, Hamilton and Coates [19] surveyed 6430 people in the UK and identified that almost half of the sample reported high anxiety, with anxiety scores showing a marked increase from pre-pandemic scores. As for many mental health conditions, anxiety is under-diagnosed, and there is a noted treatment gap for anxiety globally [20]. Even where treatment has been prescribed, it still may not be reliable or wholly effective. The main pharmacological treatments (most usually SSRIs (selective serotonin reuptake inhibitors) and SNRIs (serotonin-norepinephrine reuptake inhibitors)) have significant potential for adverse effects and drug-drug interactions [21]. Psychological therapies, such as CBT (Cognitive Behavioral Therapy), are recognized to have good efficacy but are still most effective when used in combination with pharmacological treatments [22]. Considering the long experience of testing and patient use of these medications, there is a need for different thinking about mental health therapy-perhaps toward a nature-based treatment approach.

During the COVID-19 pandemic, it was estimated that almost one in five adults experienced some form of depression, doubling from around one in ten prior to the pandemic with more than half of adults who experienced some form of depression also reporting high levels of anxiety [23]. Recognized symptoms include feeling sad or being in a depressed mood, loss of interest or pleasure in activities once enjoyed, loss of energy, and feeling worthless or guilty [24]. Treatments usually include talking therapies and medications such as TCAs (tricyclic antidepressants), SSRIs (selective serotonin reuptake inhibitors), and SNRIs (serotonin-norepinephrine reuptake inhibitors). However, some of these do not yield the intended improvements. Many of the pharmacological treatments have unpleasant side effects [25]. Furthermore, even with the extensive testing and long history of use of these conventional treatments, patients with depression can both improve and remit unexpectedly [26]. As for anxiety, these challenges suggest a need to explore new ways of thinking about therapy for depression, such as those offered by nature-based treatments.

The COVID-19 pandemic placed a heavy burden on health services including mental health services [27]. The main psychological and pharmacological therapies are heavily reliant on limited and often costly resources, leading to delays in treatment. While some service providers have responded creatively to the shortfall during the pandemic, for example, by moving CBT online to sustain the care processes [28], it is clear that mental health systems need further innovation [29]. Greater need and reduced availability should drive attention toward free and publicly accessible therapies that are not reliant on the availability of professional care processes. This rationalizes a need to consider the efficacy of nature-based therapies in a specific way.

Here, we systematically reviewed the literature for evidence of the effect of nature walks on anxiety and depression outcomes. Nature walks are walks on a trail in a natural setting such as forests, woodlands, or parks [30] that can take any time from $15 \mathrm{~min}$ [31] to a few hours [32]. Nature walks can be undertaken by diverse populations (e.g., cancer 
survivors [32], university students [33]) and conducted in any season of the year [31,34]. We focused on nature walks as an example of a nature-based therapy because they are simple and low-risk to undertake and potentially accessible to many people [35,36]. As these practical aspects are crucial in the delivery of treatment, the mental health effect of nature walks was chosen to be evaluated in this review.

\section{Materials and Methods}

This systematic review followed the preferred reporting items for systematic review and meta-analysis guidelines (PRISMA [36]) to review the literature in an organized manner and assess the quality of evidence for the psychological effects of nature walks. Klassen, Jadad, and Moher's framework [37] was used to help maintain the validity of our findings, considering question, criteria, missing articles, quality of the studies, assessment, and results. The extended version of the PICO (population, intervention, control, and outcomes) format [38] was created to establish a researchable question by focusing on four key components [39]. The primary research questions for this systematic review are (i) "How effective are nature walks for depression and anxiety?" and (ii) "What quantity and quality of evidence has been reported?"

\subsection{Literature Search}

Following a consultation with a subject librarian [40,41], four research databasesProQuest, PsycINFO, Science Direct, and Google Scholar-were accessed via EBSCO to conduct a comprehensive literature search, focusing on where, when, who, how, what, and why $[42,43]$. Articles published before 31 October 2020 were considered in this systematic review. Three hundred and eighty-three articles were retrieved with search terms "nature" AND "walk" AND "psychology" $(n=333)$ as well as "forest" AND "walk" AND "psychology" $(n=50)$ in the title and abstract (other words such as "grassland", "coastal", "greenspace", and "woodland" were searched combined with "walk" AND "psychology"; however, only a small number of articles were retrieved, and none were eligible). Additionally, manual reference searches in published reviews [43,44] identified two articles [40]. Of a total of 385 articles, 44 were duplicates and therefore were removed. Three hundred and forty-one articles were screened for title and abstract, and 45 articles were reviewed in full text, which identified 12 articles that met all eligibility criteria (Figure 1). The co-author Y.K. completed the literature search, which was then reviewed by the co-author K.C.V.

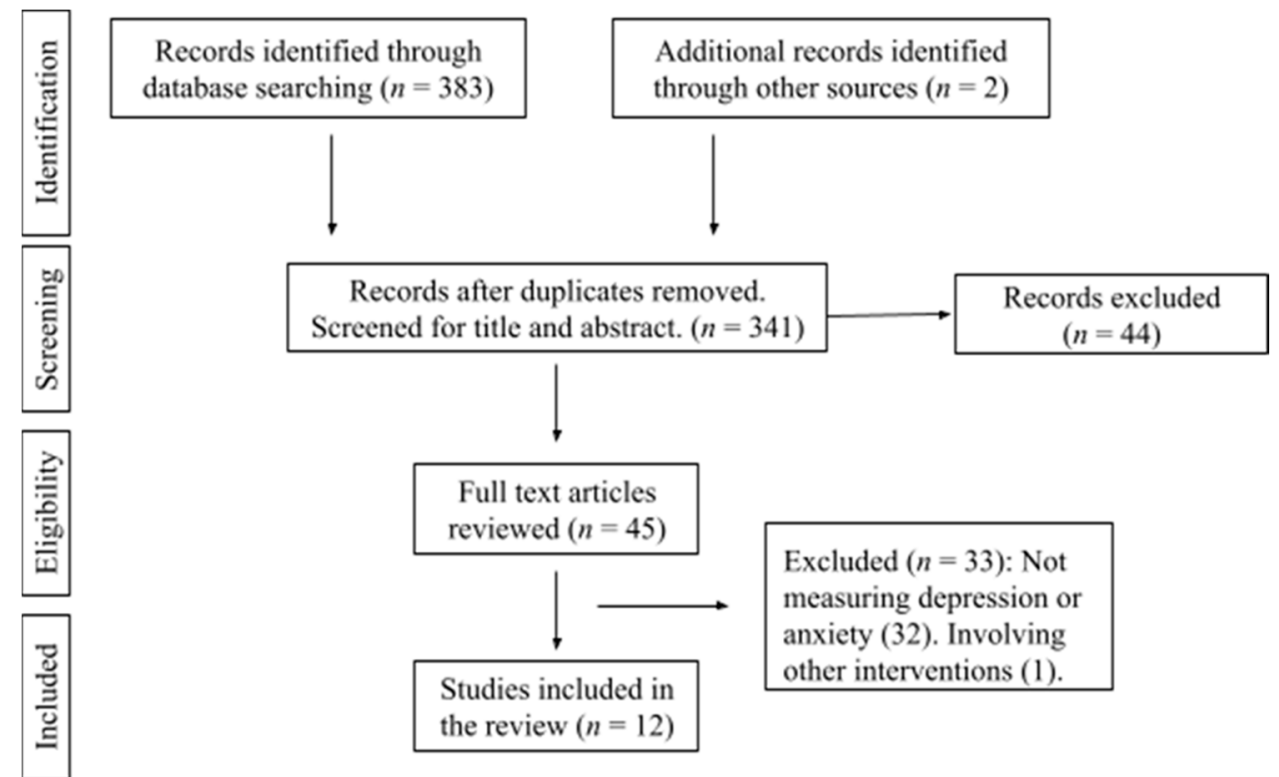

Figure 1. PRISMA flow diagram of the article selection process. 


\subsection{Selection of Studies and Outcomes}

In order to be further analyzed, articles needed to (a) include a nature walk only, (b) measure depression and/or anxiety, (c) report an empirical intervention study (i.e., pre- and post-intervention scores of depression/anxiety), and (d) be published in a peerreviewed academic journal written in the English language. Articles were excluded if they (a) included other nature-based interventions (e.g., shinrin-yoku), (b) did not measure either depression or anxiety, (c) used a single-participant design (i.e., case studies), and (d) did not examine an intervention (e.g., articles that only introduced and/or discussed concepts or research protocols) (see Table 1).

Table 1. Extended PICO for this review.

\begin{tabular}{ccc}
\hline Review Questions & $\begin{array}{c}\text { (i) How Effective Are Nature Walks for Depression and Anxiety? } \\
\text { (ii) What Quantity and Quality of Evidence Has Been Reported? } \\
\text { Exclusion Criteria }\end{array}$ \\
\hline Inclusion Criteria & $\begin{array}{c}\text { Any population } \\
\text { Intervention }\end{array}$ & $\begin{array}{c}\text { Nature walk only } \\
\text { (e.g., shinrin-yoku) }\end{array}$ \\
Comparator & $\begin{array}{c}\text { Involving other nature-based interventions } \\
\text { comparator including } \\
\text { non-comparator } \\
\text { Depression and anxiety }\end{array}$ & $\begin{array}{c}\text { Other outcomes } \\
\text { Outcomes }\end{array}$ \\
Study Design & Empirical intervention studies & $\begin{array}{c}\text { Single case studies, cross-sectional studies, qualitative } \\
\text { studies, reviews, discussion articles, articles introducing } \\
\text { theories/concepts /models/applications }\end{array}$ \\
Other & $\begin{array}{c}\text { Published in a peer-reviewed } \\
\text { academic journal in English }\end{array}$ & \\
\hline
\end{tabular}

\subsection{Data Extraction and Synthesis}

The co-author Y.K. conducted all the searches and reviewed all the search results. If the title and abstract of the article suggested a match with the eligibility criteria, the articles were shortlisted for further analysis $(n=45)$. The co-author K.C.V. reviewed the selection process to minimize any potential bias. After K.C.V.'s review, full texts of the shortlisted articles were appraised by both co-authors independently, who then discussed and agreed which articles met the eligibility criteria. No additional eligible articles were identified in forward and backward reference searches.

Using a data extraction table, developed by Sturt et al. [45], key information of included studies was presented: publication details (authors, year, and country), study design and setting, participant characteristics, details of demographic data, intervention details, outcome measures, and study findings (see Table 2).

\subsection{Quality Scoring: Assessing the Risk of Bias}

The Newcastle-Ottawa Scale (NOS) was used to appraise the methodological quality and risk of bias [46]. Star marks (0-9) were used to indicate the quality scoring for each study (high risk: 0-3, medium risk: 4-6, low risk: 7-9) regarding: (a) representativeness of study group selection (four stars maximum), (b) comparability of groups (two stars maximum), and (c) ascertainment of either the exposure or outcome of interest (three stars maximum). Because the NOS was originally designed for medical research, some adjustments were made in this review focusing on nature walk: (a) the word "exposure" was changed to "intervention" (e.g., "Ascertainment of intervention"), (b) "Demonstration that outcome of interest was not present at start of study" to "Demonstration that the measured outcome was assessed before the intervention"; and (c) a star was given if the outcome was measured using a validated psychometric scale, instead of medical records, in the first item of "Outcome" (i.e., "Assessment of Outcome"). 


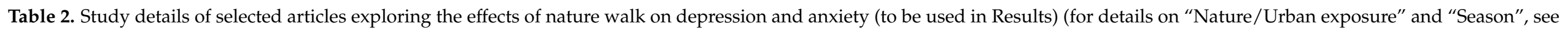
Appendix A).

\begin{tabular}{|c|c|c|c|c|c|c|c|c|c|}
\hline No. & Year & Author(s) & Country & Sample and Setting & Intervention Details & Nature/Urban Exposure & Season & Measures & Findings \\
\hline 1 & 2020 & Lesser et al. [32] & Canada & $\begin{array}{l}9 \text { adult cancer survivors } \\
\text { ( } 8 \text { females and } 1 \text { male). }\end{array}$ & $\begin{array}{c}2 \text { trail walks per week } \\
(2.5 \mathrm{~h} \text { a week for } \\
8 \text { weeks with a hiking } \\
\text { guide. }\end{array}$ & Forest—sloped area. & Not recorded. & $\begin{array}{c}\text { Generalized } \\
\text { Anxiety } \\
\text { Disorder-7 and } \\
\text { Visual Analog } \\
\text { Scale }\end{array}$ & $\begin{array}{l}\text { Significant reduction } \\
\text { in state anxiety but not } \\
\text { in generalized anxiety. }\end{array}$ \\
\hline 2 & 2020 & Janeczko et al. [47] & Poland & $\begin{array}{l}75 \text { university students } \\
\text { (nonclinical) divided } \\
\text { into either taking a walk } \\
\text { in apartment suburbs; } \\
\text { green suburbs; } \\
\text { coniferous forest; or } \\
\text { deciduous forest. }\end{array}$ & $\begin{array}{l}\text { 2-km walk (30 min) } \\
\text { keeping distance to each } \\
\text { other, not allowed to } \\
\text { talk. }\end{array}$ & $\begin{array}{c}\text { Urban: A1: single-family } \\
\text { dwellings with more } \\
\text { greenery. A2: } \\
\text { multi-family buildings } \\
\text { with less greenery. } \\
\text { Forest: B1: coniferous } \\
\text { forest; B2: deciduous } \\
\text { forest. }\end{array}$ & $\begin{array}{l}\text { One day. Late } \\
\text { autumn } \\
\text { (November). }\end{array}$ & $\begin{array}{l}\text { Profile of Mood } \\
\text { States (POMS) }\end{array}$ & $\begin{array}{l}\text { Depression was } \\
\text { reduced in all groups } \\
\text { from pre- to post-walk. } \\
\text { No difference was } \\
\text { found among groups. }\end{array}$ \\
\hline 3 & 2019 & Koselka et al. [48] & USA & $\begin{array}{c}38 \text { participants (age } \\
\text { range } 18-35 ; 22.9+ \\
4.6 \text { years; } 20 \text { females and } \\
18 \text { males; nonclinical) } \\
\text { divided into (i) } 50-\text { min } \\
\text { nature walk, (ii) } 50-\text { min } \\
\text { walk on busy road, and } \\
\text { (iii) activity of daily } \\
\text { living. Crossover design. }\end{array}$ & $\begin{array}{c}\text { 50-min walk at } \\
\text { moderate-intense pace } \\
\text { with } 9 \text { days of washout } \\
\text { period. }\end{array}$ & $\begin{array}{l}\text { Busy road; } \\
\text { forest. }\end{array}$ & Not recorded. & $\begin{array}{l}\text { State-Trait Anxiety } \\
\text { Inventory (STAI) }\end{array}$ & $\begin{array}{l}\text { Nature walk reduced } \\
\text { state anxiety. }\end{array}$ \\
\hline 4 & 2019 & Song et al. [31] & Japan & $\begin{array}{l}12 \text { female university } \\
\text { students (age of the } \\
\text { approaches sample } \\
(n=60) \text { was } 21.0 \pm \\
1.3 \text { years) walked for } \\
15 \text { min either in a forest } \\
\text { or urban environment. }\end{array}$ & $\begin{array}{c}\text { 15-min nature walk and } \\
\text { urban walk crossover } \\
\text { next day. }\end{array}$ & $\begin{array}{l}\text { Six locations, with a } \\
\text { paired city and } \\
\text { secondary forest site } \\
\text { (mixed oak woodlands). }\end{array}$ & Summer. & POMS and STAI & $\begin{array}{l}\text { Nature walk reduced } \\
\text { depression and } \\
\text { anxiety, and state } \\
\text { anxiety significantly } \\
\text { more than urban walk. }\end{array}$ \\
\hline 5 & 2018 & Hassan et al. [33] & China & $\begin{array}{c}60 \text { nonclinical university } \\
\text { students ( } 30 \text { females and } \\
30 \text { males; mean age, } 19.6 \\
\pm 1.42 \text { years) randomly } \\
\text { allocated to a } 15 \text {-min } \\
\text { nature or urban walk. }\end{array}$ & $\begin{array}{c}\text { 15-min nature walk and } \\
\text { urban walk crossover } \\
\text { next day. }\end{array}$ & $\begin{array}{c}\text { Urban area; } \\
\text { bamboo forest. }\end{array}$ & $\begin{array}{l}\text { One day. Season } \\
\text { not specified. }\end{array}$ & STAI & $\begin{array}{l}\text { Nature walk reduced } \\
\text { state anxiety. }\end{array}$ \\
\hline
\end{tabular}


Table 2. Cont

\begin{tabular}{|c|c|c|c|c|c|c|c|c|c|}
\hline No. & Year & Author(s) & Country & Sample and Setting & Intervention Details & $\begin{array}{c}\text { Nature/Urban } \\
\text { Exposure }\end{array}$ & Season & Measures & Findings \\
\hline 6 & 2018 & Song et al. [49] & Japan & $\begin{array}{l}585 \text { Japanese male } \\
\text { students (Age } 21.7 \pm \\
1.6 \text { years) walked for } \\
15 \text { min either in a } \\
\text { forest or urban } \\
\text { environment. } \\
\text { Crossover next day. }\end{array}$ & $\begin{array}{l}\text { 15-min nature walk } \\
\text { and urban walk } \\
\text { crossover next day. }\end{array}$ & $\begin{array}{l}\text { City areas were either } \\
\text { downtown or near a } \\
\text { train station; "Safe, } \\
\text { well-maintained" } \\
\text { forest areas. }\end{array}$ & Summer. & POMS and STAI & $\begin{array}{l}\text { Nature walk } \\
\text { reduced depression } \\
\text { and anxiety, and } \\
\text { trait anxiety } \\
\text { significantly more } \\
\text { than urban walk. }\end{array}$ \\
\hline 7 & 2016 & $\begin{array}{c}\text { Korpela et al. } \\
{[50]}\end{array}$ & Finland & $\begin{array}{l}13 \text { depression patients } \\
\text { ( } 9 \text { females and } \\
4 \text { males; age range } \\
29-59 \text { years, } M=48 \\
\text { Md }=52 \text { years). }\end{array}$ & $\begin{array}{c}\text { 2-h walk a week for } \\
8 \text { weeks }\end{array}$ & $\begin{array}{l}\text { Park with a lake and } \\
\text { ornamental plantings; } \\
\text { urban woodland. }\end{array}$ & $\begin{array}{l}\text { Recruitment in } \\
\text { spring. }\end{array}$ & $\begin{array}{l}\text { Beck Depression } \\
\text { Inventory }\end{array}$ & $\begin{array}{l}\text { Depression reduced } \\
\text { from pre- to } \\
\text { post-walk, and } \\
\text { post-walk to } \\
\text { 3-month follow-up. }\end{array}$ \\
\hline 8 & 2015 & $\begin{array}{c}\text { Bratman et al. } \\
\text { [51] }\end{array}$ & USA & $\begin{array}{l}60 \text { nonclinical adults } \\
(33 \text { females and } \\
27 \text { males, total mean } \\
\text { age }=22.9 \text { years }) \\
\text { randomly assigned to } \\
\text { nature or urban } \\
\text { individual walk for } \\
50 \text { min. }\end{array}$ & $\begin{array}{l}\text { Participants were told } \\
\text { to take good pictures } \\
\text { to blind the } \\
\text { intervention. Nature } \\
\text { group comprised } \\
30 \text { participants } \\
\text { (18 females and } \\
12 \text { males, total mean } \\
\text { age }=22.8) \text {, and urban } \\
\text { group also comprised } \\
30 \text { participants } \\
(15 \text { females and } \\
15 \text { males, total mean } \\
\text { age }=22.9) .\end{array}$ & $\begin{array}{l}\text { Urban walk: adjacent } \\
\text { to a major road. } \\
\text { Nature walk: } \\
\text { grassland, scattered } \\
\text { shrub, and oak trees. }\end{array}$ & $\begin{array}{l}\text { Equal spread } \\
\text { across autumn, } \\
\text { winter, spring, } \\
\text { and summer. }\end{array}$ & STAI & $\begin{array}{l}\text { Nature walk } \\
\text { reduced anxiety, } \\
\text { relative to urban } \\
\text { walk (separate data } \\
\text { on state and trait } \\
\text { anxiety were not } \\
\text { reported). }\end{array}$ \\
\hline 9 & 2015 & Song et al. [52] & Japan & $\begin{array}{c}20 \text { middle-aged } \\
\text { hypertensive } \\
\text { individuals ( } 58.0 \pm \\
10.6 \text { years) walked for } \\
17 \text { min either in a } \\
\text { forest or urban } \\
\text { environment. } \\
\text { Crossover next day. }\end{array}$ & $\begin{array}{l}\text { 17-min nature walk } \\
\text { and urban walk } \\
\text { crossover next day. }\end{array}$ & $\begin{array}{l}\text { City; coniferous } \\
\text { forest. }\end{array}$ & $\begin{array}{l}\text { Not recorded } \\
\text { (however, the } \\
\text { average } \\
\text { temperature of } \\
\text { the forest was } 24 \\
{ }^{\circ} \mathrm{C} \text { and urban } \\
\text { was } 28^{\circ} \mathrm{C} \text { ). }\end{array}$ & POMS & $\begin{array}{l}\text { Nature walk } \\
\text { reduced depression } \\
\text { and anxiety } \\
\text { significantly more } \\
\text { than urban walk. }\end{array}$ \\
\hline
\end{tabular}


Table 2. Cont

\begin{tabular}{|c|c|c|c|c|c|c|c|c|c|}
\hline No. & Year & Author(s) & Country & Sample and Setting & Intervention Details & $\begin{array}{c}\text { Nature/Urban } \\
\text { Exposure }\end{array}$ & Season & Measures & Findings \\
\hline 10 & 2015 & Song et al. [53] & Japan & $\begin{array}{l}23 \text { male university } \\
\text { students (age } 22.3 \pm \\
1.2 \text { years) walked for } \\
15 \text { min either in a } \\
\text { forest or urban } \\
\text { environment. } \\
\text { Crossover next day. }\end{array}$ & $\begin{array}{l}\text { 15-min nature walk } \\
\text { and urban walk } \\
\text { crossover next day. }\end{array}$ & $\begin{array}{l}\text { Park that contained } \\
\text { many hardwood trees } \\
\text { and a large pond; } \\
\text { urban residential area. }\end{array}$ & $\begin{array}{l}\text { Autumn } \\
\text { (October) }\end{array}$ & POMS and STAI & $\begin{array}{l}\text { Nature walk } \\
\text { reduced depression } \\
\text { and anxiety } \\
\text { significantly more } \\
\text { than urban walk. }\end{array}$ \\
\hline 11 & 2014 & $\begin{array}{c}\text { Marselle et al. } \\
\text { [54] }\end{array}$ & England & $\begin{array}{l}1516 \text { participants }(66 \% \\
\text { were female, and } 88 \% \\
\text { were aged } 55 \text { years or } \\
\text { older) who had } \\
\text { attended at least one } \\
\text { session in the Walk } \\
\text { for Health (WfH) } \\
\text { program responded } \\
\text { to online survey. }\end{array}$ & $\begin{array}{l}\text { WfH attendee who } \\
\text { continued to walk } \\
\text { during the 13-month } \\
\text { of the research period } \\
\text { was defined as Nature } \\
\text { Group Walker, and } \\
\text { those who did not as } \\
\text { Non-Group Walker. } \\
1081 \text { Nature Group } \\
\text { Walkers and } \\
435 \text { Non-Group } \\
\text { Walkers were } \\
\text { identified. }\end{array}$ & $\begin{array}{l}\text { Nature: "natural and } \\
\text { semi-natural places, } \\
\text { green corridor, } \\
\text { farmland, urban } \\
\text { green space, coastal, } \\
\text { or a mixture of any of } \\
\text { the above". }\end{array}$ & Not recorded. & $\begin{array}{l}\text { 10-item Major } \\
\text { Depressive } \\
\text { Inventory }\end{array}$ & $\begin{array}{l}\text { Group nature walk } \\
\text { reduced depression } \\
\text { from } \mathrm{T} 1 \text { to } \mathrm{T} 2 .\end{array}$ \\
\hline 12 & 2013 & Song et al. [55] & Japan & $\begin{array}{c}13 \text { male university } \\
\text { students (nonclinical) } \\
\text { aged } 22.5 \pm 3.1 \text { years } \\
\text { divided into park } \\
\text { walk and city walk. } \\
\text { Crossover design. }\end{array}$ & $\begin{array}{l}\text { 15-min walk in urban } \\
\text { parks and city }\end{array}$ & $\begin{array}{l}\text { Urban park-treed; } \\
\text { city area. }\end{array}$ & $\begin{array}{l}\text { One day. } \\
\text { Late autumn } \\
\text { (November). }\end{array}$ & POMS and STAI & $\begin{array}{l}\text { Nature walk } \\
\text { reduced anxiety } \\
\text { (both POMS and } \\
\text { STAI) but not } \\
\text { depression. }\end{array}$ \\
\hline
\end{tabular}




\section{Results}

\subsection{Characteristics of the Studies}

Of the 12 included studies, nine were pre-post within-subject studies [31-33,48-50,52, 53,55], two were quasi-experimental studies [34,54], and one was an experimental betweensubjects study [51]. Study location varied considerably (see Table 2), six studies were conducted in Asia (China and Japan), three were in North America (USA and Canada) and in Europe (England, Finland, and Poland). Nine of the studies compared a nature walk with an urban walk, one compared a nature walk with no walk, and one study included the assessment of the outcomes in a typical day that did not involve walking in any of the settings.

Regarding the psychological outcomes, eight of the included studies assessed anxiety through either the Generalized Anxiety Disorder-7 or the State-Trait Anxiety Inventory; two studies assessed depression using either the Beck Depression Inventory-II or the Major Depressive Inventory, and six assessed mood using the Profile of Mood States. Sample sizes were generally small $(<100)$ for all but the Song et al. [49] and Marselle et al. studies [54].

Overall, the studies demonstrated that nature walks were successful in reducing state anxiety [31-33,48,51,55], but the effects on generalized, trait anxiety were mixed [32,49]. In six studies, a significant reduction in depression was also observed [31,34,49,50,52,53]. However, Janeczko et al. [47] reported a reduction in depression regardless of the type of walking (nature or urban). In fact, the impact of nature walking on depression appears to be less consistent and was not observed by Song et al. [55].

Regarding the environments where nature walks were undertaken, eight studies were in a forest or woodland [31-34,48,49,52,55], three studies included more than one type of nature $[50,53,54]$, and one study was in a predominantly grassland environment [51]. There were water features present near the route in three studies $[48,50,53]$. Forest types varied considerably between studies, including a bamboo forest [33], deciduous trees [34,55], and coniferous forest [47], and four studies did not provide enough detail to determine the type [32,48-50]. Three studies were undertaken in autumn [34,53,55], three were in spring/summer $[31,49,50]$, one study spanned four seasons but indicated little seasonal variation in the region [51], one likely varied but was not specified [54], and three did not specify, although images and descriptions implied trees were in leaf [32,33,48,52].

\subsection{Risk of Bias}

The risk of bias of the 12 included studies was deemed to be medium to high (see Table 3). Five studies were deemed medium-risk $[34,48,50,51,54]$, especially due to a lack of a control group and for assessing the follow-up immediately after the intervention. In only three of these studies was the representativeness of the sample adequately addressed [34,48,54]. Bratman et al.'s [51] scored particularly well in comparability. Marselle et al. [54] had the largest sample amongst all selected studies $(n>1000)$, but the experimental group was twice as large as the control group, and the researchers did not measure the outcome before the intervention.

Finally, seven studies were deemed to have a high risk of bias [31-33,49,51,52,55]. Two studies conducted a within-subject design with small samples [33,55]. None of the studies assessed the outcome before the intervention and only tested the effect immediately after the intervention, not considering long-term effects. 
Table 3. Assessment of risk of bias for intervention studies.

\begin{tabular}{|c|c|c|c|c|c|c|c|c|c|}
\hline Bias Category & & & & & Comparability & & Outcome & & \\
\hline Author (Year) & 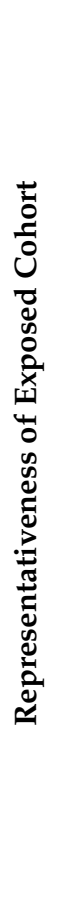 & 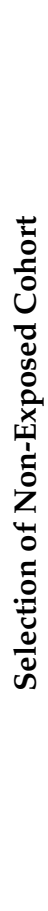 & 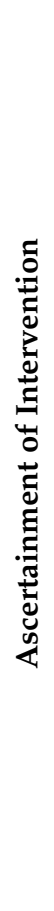 & 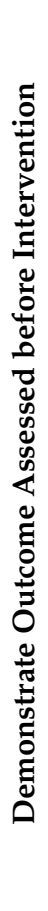 & 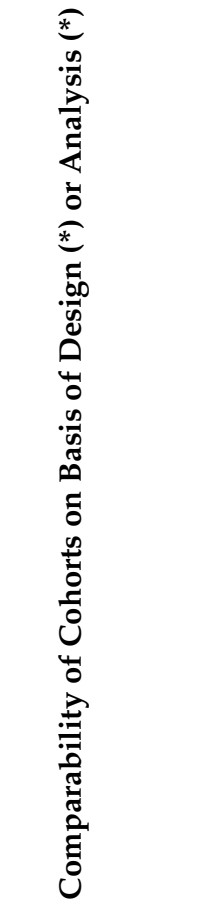 & 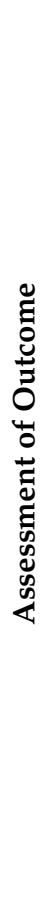 & 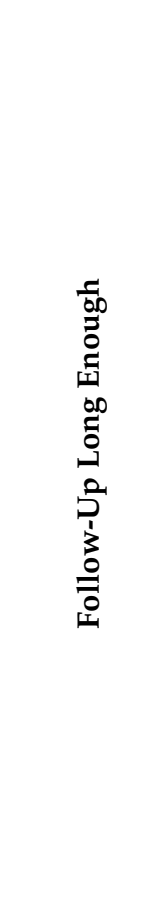 & 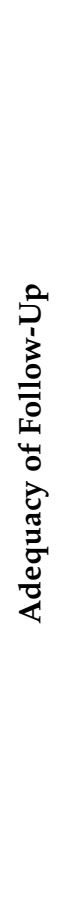 & $\begin{array}{l}\text { Number of } \\
\text { Stars (0-9) }\end{array}$ \\
\hline Lesser et al. (2020) [32] & & & * & * & & * & & & 3 \\
\hline Janeczko et al. (2020) [47] & * & * & * & * & & * & & & 5 \\
\hline Koselka et al. (2019) [48] & * & & * & * & & * & & & 4 \\
\hline Song et al. (2019) [31] & & & * & & & * & & & 2 \\
\hline Hassan et al. (2018) [33] & & & * & & & * & & & 2 \\
\hline Song et al. (2018) [49] & & & * & & & * & & & 2 \\
\hline Korpela et al. (2016) [50] & & & * & * & & * & * & * & 5 \\
\hline Bratman et al. (2015) [51] & & * & * & * & $* *$ & * & & & 6 \\
\hline Song et al. (2015) [52] & & & * & & & * & & & 2 \\
\hline Song et al. (2015) [53] & & & * & & & * & & & 2 \\
\hline Marselle et al. (2014) [54] & $*$ & * & * & & * & * & & & 5 \\
\hline Song et al. (2013) [55] & & & * & & & * & & & 2 \\
\hline
\end{tabular}

* (star mark) indicates that the study addressed the assessment item.

\section{Discussion}

This systematic review examined the quality and extent of evidence in studies investigating the effects of nature walks on depression and anxiety. Only 12 studies were identified focusing specifically on an empirical evaluation of this intervention and reported in English language peer-reviewed journals. Nature walks were found to reduce state anxiety consistently but not generalized anxiety. There were no clear effects of nature walks on depression in these studies. The small sample size and large variation in approach to the studies mean it is not possible to draw conclusions about the type of nature walk that would be most beneficial or who would benefit most from these.

The health benefits of spending time in nature [56-58] and of walking $[59,60]$ are well established. This review has found there are very few studies focusing specifically on walking in nature for two specific mental health outcomes: anxiety and depression. Consistent with studies focused just on walking, the effects on anxiety and depression reported in studies included in this review were positive or neutral [61,62]. As reported in a meta-analysis on forest bathing [63], anxiety was the one mental health condition for which nature walks were consistently reported to be beneficial. More specifically, the current review identified that nature walks were effective for state anxiety but not for generalized anxiety. This may be explained by the soothing effects of phytoncides, 
antimicrobial organic compounds released from plants [64], which are known to reduce stress and anxiety [64]. Indeed, phytoncides were also related to reduced depression on a self-report measure [65]; however, more robust biological evidence supports a link between phytoncides and anxiety [66]. Further research is needed to examine these specific pathways through which nature walks provide mental health benefits.

A number of reviews looking at the physical and mental health benefits of walking have identified a lack of consistency in study design and could therefore not draw strong conclusions about the benefits and most effective interventions [67-69]. This challenge is reflected in our review, where studies varied substantially in the participant group composition and the intervention details. Participant groups included people with preexisting physical health conditions (cancer [32]), pre-existing mental health conditions (depression [50]), any participant (but health controlled for [54]), or primarily healthy subjects. Variation in participant groups made drawing any conclusions particularly difficult in relation to depression outcomes, which were examined in only three studies. Marselle et al. [54] found group walks in nature to be a strong predictor of lower depression symptoms, while two studies focused on individuals found opposite effects of nature walks on depression symptoms [34,55]. It is possible that walking in a group was the important aspect of Marselle et al.'s study [54], although Janeczko et al. [47] also found lowered depression symptoms on individual walks, and previous work has similarly found inconclusive results of the benefits of group over individual activity [61]. A previous systematic review has found walking to reduce depression symptoms [61] and that exercise more generally is important in reducing depression symptoms [70,71], and it may be that the act of walking rather than the environment the walk is in is what is important for depression. There is insufficient evidence from the studies included in this review to draw a robust conclusion.

The details of the intervention varied between studies. Lesser et al. [32] involved walks up notable slopes, while two studies noted the route was flat [33,51]. Walk duration varied from $2.5 \mathrm{~h}$ a week over multiple weeks [32] through to a single, 15-min route [33,55]. Janeczko et al. [47] found walking duration to have an important effect on all outcomes, indicating these interventions are not comparable. The appropriate time "dose" of walking is not well understood [62], and our review suggests the methodological approach needs to be strengthened in future studies. This information is available for exercise more generally [70], and methodological approaches could be extrapolated to the nature walk context. None of the studies in this review compared walking to other treatment approaches (pharmacological treatments or psychological therapies) although previous work has suggested that treatment of depression with exercise may be most effective when combined with a pharmacological approach [68]. Another aspect of the studies related to time is the duration of effect. None of these studies assessed long-term effects of any of the interventions, although one did indicate the study was a pilot, and the intention was to follow up with a longitudinal study [48], which would be a welcome addition.

A key benefit identified for nature-based therapies is that they are free and publicly accessible, in principle. Nature is not equally accessible to everyone, however [72], and even where some form of nature is available it is not always of the same "quality" [73]. In working toward recommendations for nature-based health interventions, it is important to understand what nature is most beneficial to address both equity of provision and to consider health outcomes in the context of other functions and benefits provided by both greenspace [74] and blue space [75]. It was not possible in this study to look for effects of particular types of natural environment as the environment varied considerably between studies, from the broad vegetation type (e.g., forest vs. grassland), the inclusion of additional features (e.g., water), and the season of study (autumn vs. spring/summer) (Appendix A). There is a growing body of literature suggesting that people's response to nature varies depending on very specific measures of the environment, including vegetation structure [76,77], leaf color and shape [78], season [79], perceived biodiversity [80,81], and infrastructure on and management of the site [82]. Within the included studies, only 
one directly controlled for different aspects of the environment in their site selection [47], and only a subset measured additional features of the environment [33,34,55]. In most of the reviewed studies, it is not possible to separate out the influence of the different aspects of the environmental conditions in the walking environments that may have been providing any benefit. For example, two studies compared a nature walk with a walk by a busy road $[51,55]$. These two environments differ on a wide range of metrics including temperature, humidity (measured in Song et al. [55], Hassan et al. [33], and Janeczko et al. [47]), light levels (measured in Song et al. [55]), noise pollution (measured in Janeczko et al. [47]), air pollution, physical disturbances (e.g., passing cars), colors, and shapes of the visual landscape. To parse out the relative importance of these features, studies testing the different elements of the environment would be beneficial. Future studies addressing the types of vegetation, vegetation context (including associated infrastructure), the season, and the levels of biodiversity most beneficial for achieving health benefits from nature walks would be important contributions to the literature $[74,80,83]$.

As outlined above, the studies included in this review were not sufficiently comparable in study design, participant selection, or intervention approach to draw robust conclusions about the benefits of nature walks as an intervention for anxiety or depression. The consistently positive effect of nature walks on state anxiety measures combined with the medium to high risk of bias in the majority of studies included in this review suggest a need for more targeted research in order to develop recommendations for health practice. Despite the small number of studies, three continents were included (Asia, North America, and Europe). Variation in effect between continents, country, and climatic region is an area where future research would be beneficial. Consistent patterns across regions could be sought by focusing on the environmental conditions and specific measures of the natural environment (as above). None of the studies were randomized controlled trials. One study did blind the participants to the purpose of the study. The mental health benefit of walking in nature is a growing area of research and is reflected in the publication dates of the studies included in this review, six of which were published in the last four years and all published within the last nine years. There is a great deal of scope for undertaking more controlled studies on this intervention for this area to continue to develop.

This review had four primary limitations. The first is that only studies published in English-language academic journals were included. The number of studies missed because of this is not known. The second is focusing on articles that are studying walks exclusively. This strengthens the conclusions as the results can be confirmed to focus on walks, but studies that report outcomes of nature walks in conjunction or addition to other interventions may have been missed (e.g., studies that combined walking and viewing [84]). The third limitation is in the specific aims of the included studies. While the broad goal of all studies was to look at the effects of a nature or forest walk, the variation in how these were measured reflects differences in the specific aims. Nine of the studies focused on comparing the relative effects of a nature walk in contrast to an urban walk [31,34,45,47-49,52,53,55], two studies compared measures before and after a walk $[32,50]$ and one study compared walking to not walking [54]. As the literature on this topic grows, teasing apart these different comparisons would be worthwhile. Lastly, this study did not focus on "park walks", as the richness of nature can be significantly limited in some parks: indeed, some of the included nature walk studies in this review were conducted in the park; however, the richness of nature was reported. Close examination of park walk literature can offer additional insights.

\section{Conclusions}

The 12 studies identified through this review focused specifically on the effects of nature walks on anxiety and depression and suggest that state anxiety can be reduced through nature walks. The effect of nature walks on generalized anxiety was mixed. The evidence for effects of nature walks on depression symptoms was inconclusive. The low number of studies with high variability in the subjects and the type of nature subjects were 
exposed to in these studies suggest more work is required. Given the global challenges to healthcare systems of anxiety and depression and the relatively cost-effective treatment intervention of a walk in nature, the establishment of a more robust research base on this topic is warranted.

Author Contributions: Conceptualization, Y.K.; methodology, Y.K.; validation, Y.K., M.L., K.C.V., and B.N.; formal analysis, K.C.V.; investigation, K.C.V. and B.N.; data curation, K.C.V. and B.N.; writing — original draft preparation, Y.K., M.L., K.C.V., and B.N.; writing—review and editing, Y.K., M.L., K.C.V., and B.N. All authors have read and agreed to the published version of the manuscript.

Funding: This research received no external funding.

Institutional Review Board Statement: Not Applicable.

Informed Consent Statement: Not Applicable.

Data Availability Statement: No new data were created or analyzed in this study. Data sharing is not applicable to this article.

Conflicts of Interest: The authors declare no conflict of interest.

\section{Appendix A}

Table A1. Selected articles exploring the effects of nature walk on depression and anxiety with study details. Full study details are in Table 2 of the main text. Here, "Location" is added, and "Nature/Urban exposure" and "Season" are expanded to include more detail from the papers.

\begin{tabular}{|c|c|c|c|c|c|c|}
\hline No. & Year & Author(s) & Country & Location & Nature/Urban Exposure & Season \\
\hline 1 & 2020 & Lesser et al. [32] & Canada & $\begin{array}{l}\text { Participants from } \\
\text { Fraser Valley, British } \\
\text { Columbia, Canada }\end{array}$ & $\begin{array}{l}\text { "Lush green old growth forest". } \\
\text { Sloped. }\end{array}$ & $\begin{array}{l}\text { Not recorded. Description } \\
\text { suggests trees are in leaf. }\end{array}$ \\
\hline 2 & 2020 & $\begin{array}{c}\text { Janeczko et al. } \\
\text { [47] }\end{array}$ & Poland & Warsaw & $\begin{array}{l}\text { Urban: A1 "among single-family } \\
\text { buildings with lots of greenery", } \\
\text { "noticeably higher level of noise, the } \\
\text { presence of a wide two-lane street, } \\
\text { dominating apartment blocks and a } \\
\text { smaller share of green space", green } \\
\text { ratio = } 12.62 \% \text {; A2 "multi-family } \\
\text { buildings dominated and the share of } \\
\text { greenery was smaller", "a quiet } \\
\text { community with detached houses and } \\
\text { green areas", green ratio = } 10.5 \% \text {. } \\
\text { Forest: B1: Kabaty Forest coniferous } \\
\text { forest, "species composition is } \\
\text { dominated by pines accompanied by } \\
\text { oaks and a share of younger birches } \\
\text { and a multitude of limes", green ratio } \\
=0.58 \% \text {; B2: Sobieski Forest, } \\
\text { deciduous forest, "dominated by } \\
\text { broadleaved species, with an old } \\
\text { forest, } 120-160 \text { years old, and } \\
\text { numerous types of trees, such as oaks, } \\
\text { pines, and beeches", green ratio }=0.0 \% \text {. } \\
\text { Sample photos and aerial images } \\
\text { included. }\end{array}$ & $\begin{array}{l}\text { One day. } \\
\text { Late autumn (November). } \\
\text { Outdoor temperature } 10 \text { a.m. } \\
9.2^{\circ} \mathrm{C} \text { at } 10 \text { a.m. in urban } \\
\text { areas, } 8^{\circ} \mathrm{C} \text { in the forest. Also } \\
\text { recorded: pressure, wind } \\
\text { speed, humidity, sound, and } \\
\text { light. }\end{array}$ \\
\hline
\end{tabular}


Table A1. Cont.

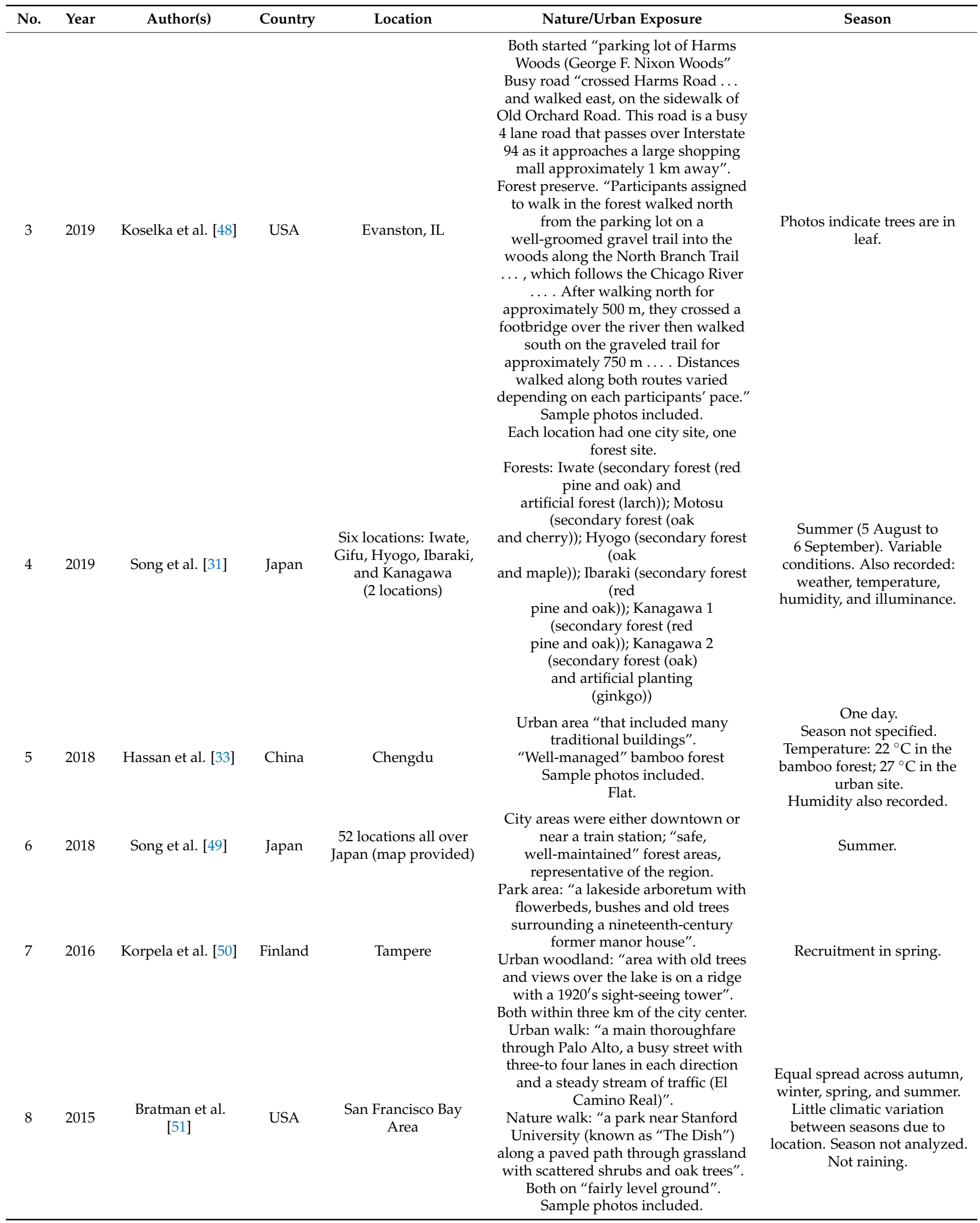


Table A1. Cont.

\begin{tabular}{|c|c|c|c|c|c|c|}
\hline No. & Year & Author(s) & Country & Location & Nature/Urban Exposure & Season \\
\hline 9 & 2015 & Song et al. [52] & Japan & Nagano & $\begin{array}{l}\text { City; coniferous forest with Japanese } \\
\text { cypress trees (Akasawa Shizen } \\
\text { Kyuyourin; Akasawa natural } \\
\text { recreation forest). Image provided. }\end{array}$ & $\begin{array}{l}\text { Not recorded. Average } \\
\text { temperature: forest was } 21.4 \\
\pm 1.2^{\circ} \mathrm{C} \text {, urban was } 28.1 \pm 1.1 \\
{ }^{\circ} \mathrm{C} \text {. Humidity also recorded. }\end{array}$ \\
\hline 10 & 2015 & Song et al. [53] & Japan & Chiba & $\begin{array}{l}\text { Park (Kashiwa-no-ha Park) that } \\
\text { contained many hardwood trees (e.g., } \\
\text { maple, tulip trees, cherry trees, and } \\
\text { chestnut) and a large } \\
\text { pond; urban residential area. }\end{array}$ & $\begin{array}{l}\text { Autumn }(7,15,16 \text { October }) \\
\text { Variable weather. } \\
\text { Temperature: park } 18.0 \pm 1.7 \text {; } \\
\text { city } 19.2 \pm 1.9 . \\
\text { Humidity and illumination } \\
\text { also recorded. }\end{array}$ \\
\hline 11 & 2014 & $\begin{array}{c}\text { Marselle et al. } \\
\text { [54] }\end{array}$ & England & Whole country. & $\begin{array}{c}\text { Nature: "natural and semi-natural } \\
\text { places, green corridor, farmland, urban } \\
\text { green space, coastal, or a mixture of } \\
\text { any of the above". }\end{array}$ & Not recorded. \\
\hline 12 & 2013 & Song et al. [55] & Japan & Chiba & $\begin{array}{c}\text { Urban park. Kashiwanoha Park. Treed. } \\
\text { City area. } \\
\text { Images provided. }\end{array}$ & $\begin{array}{l}\text { One day. } \\
\text { Late autumn (November). } \\
\text { "Trees in the park had either } \\
\text { lost their leaves or the leaves } \\
\text { had turned red or yellow". } \\
\text { Sunny. Temperature: } 14.0^{\circ} \mathrm{C} \\
\text { in the city, } 13.8^{\circ} \mathrm{C} \text { in the park. } \\
\text { Humidity and intensity of } \\
\text { illumination also reported. }\end{array}$ \\
\hline
\end{tabular}

\section{References}

1. Frumkin, H.; Bratman, G.N.; Breslow, S.J.; Cochran, B.; Kahn, P.H., Jr.; Lawler, J.J.; Levin, P.S.; Tandon, P.S.; Varanasi, U.; Wolf, K.L.; et al. Nature Contact and Human Health: A Research Agenda. Environ. Health Perspect. 2017, 125, 075001. [CrossRef] [PubMed]

2. Richardson, M.; Passmore, H.; Barbett, L.; Lumber, R.; Thomas, R.; Hunt, A. The green care code: How nature connectedness and simple activities help explain pro-nature conservation behaviours. People Nat. 2020, 2, 821-839. [CrossRef]

3. Howell, A.J.; Dopko, R.L.; Passmore, H.-A.; Buro, K. Nature connectedness: Associations with well-being and mindfulness. Personal. Individ. Differ. 2011, 51, 166-171. [CrossRef]

4. Brymer, E.; Gray, T. Dancing with nature: Rhythm and harmony in extreme sport participation. J. Adventure Educ. Outdoor Learn. 2009, 9, 135-149. [CrossRef]

5. Martin, L.; White, M.P.; Hunt, A.; Richardson, M.; Pahl, S.; Burt, J. Nature contact, nature connectedness and associations with health, wellbeing and pro-environmental behaviours. J. Environ. Psychol. 2020, 68, 101389. [CrossRef]

6. Berg, A.E.V.D. From Green Space to Green Prescriptions: Challenges and Opportunities for Research and Practice. Front. Psychol. 2017, 8, 268. [CrossRef]

7. Cox, D.T.C.; Shanahan, D.F.; Hudson, H.L.; Plummer, K.E.; Siriwardena, G.M.; Fuller, R.A.; Anderson, K.; Hancock, S.; Gaston, K.J. Doses of Neighborhood Nature: The Benefits for Mental Health of Living with Nature. BioScience 2017, 67, biw173. [CrossRef]

8. Haaland, C.; Bosch, C.K.V.D. Challenges and strategies for urban green-space planning in cities undergoing densification: A review. Urban For. Urban Green. 2015, 14, 760-771. [CrossRef]

9. McEwan, K.; Giles, D.; Clarke, F.; Kotera, Y.; Evans, G.; Terebenina, O.; Minou, L.; Teeling, C.; Basran, J.; Wood, W.; et al. A Pragmatic Controlled Trial of Forest Bathing Compared with Compassionate Mind Training in the UK: Impacts on Self-Reported Wellbeing and Heart Rate Variability. Sustainability 2021, 13, 1380. [CrossRef]

10. Olafsdottir, G.; Cloke, P.; Schulz, A.; Van Dyck, Z.; Eysteinsson, T.; Thorleifsdottir, B.; Vögele, C. Health Benefits of Walking in Nature: A Randomized Controlled Study Under Conditions of Real-Life Stress. Environ. Behav. 2020, 52, 248-274. [CrossRef]

11. Marselle, M.R.; Warber, S.L.; Irvine, K.N. Growing Resilience through Interaction with Nature: Can Group Walks in Nature Buffer the Effects of Stressful Life Events on Mental Health? Int. J. Environ. Res. Public Health 2019, 16, 986. [CrossRef]

12. Hansen, M.M.; Jones, R.; Tocchini, K. Shinrin-Yoku (Forest Bathing) and Nature Therapy: A State-of-the-Art Review. Int. J. Environ. Res. Public Health 2017, 14, 851. [CrossRef] [PubMed]

13. World Health Organization. Mental Disorders. 2018. Available online: https://www.who.int/news-room/fact-sheets/detail/ mental-disorders (accessed on 25 June 2019).

14. Ritchie, H.; Roser, M.; Mental health. Our World Data 2018. Available online: https://ourworldindata.org/mental-health (accessed on 2 April 2021).

15. Auerbach, J.; Miller, B.F. COVID-19 Exposes the Cracks in Our Already Fragile Mental Health System. Am. J. Public Health 2020, 110, 969-970. [CrossRef] [PubMed]

16. Jia, R.; Ayling, K.; Chalder, T.; Massey, A.; Broadbent, E.; Coupland, C.; Vedhara, K. Mental health in the UK during the COVID-19 pandemic: Cross-sectional analyses from a community cohort study. BMJ Open 2020, 10, e040620. [CrossRef] 
17. Kotera, Y.; Ozaki, A.; Miyatake, H.; Tsunetoshi, C.; Nishikawa, Y.; Tanimoto, T. Mental health of medical workers in Japan during COVID-19: Relationships with loneliness, hope and self-compassion. Curr. Psychol. 2021, 1, 1-4. [CrossRef]

18. American Psychiatric Association. What Are Anxiety Disorders? 2017. Available online: https://www.psychiatry.org/patientsfamilies/anxiety-disorders/what-are-anxiety-disorders (accessed on 4 March 2021).

19. Hamilton, M.; Coates, S. Coronavirus and Anxiety, Great Britain. London. June 2020. Available online: https://www.ons.gov.uk/ peoplepopulationandcommunity/wellbeing/articles/coronavirusandanxietygreatbritain/3april2020to10may2020 (accessed on 4 March 2021).

20. Alonso, J.; Liu, Z.; Evans-Lacko, S.; Mph, E.S.; Sampson, N.A.; Chatterji, S.; Abdulmalik, J.; Aguilar-Gaxiola, S.; Al-Hamzawi, A.; Andrade, L.; et al. Treatment gap for anxiety disorders is global: Results of the World Mental Health Surveys in 21 countries. Depress. Anxiety 2018, 35, 195-208. [CrossRef] [PubMed]

21. Bandelow, B.; Reitt, M.; Röver, C.; Michaelis, S.; Görlich, Y.; Wedekind, D. Efficacy of treatments for anxiety disorders. Int. Clin. Psychopharmacol. 2015, 30, 183-192. [CrossRef] [PubMed]

22. Bandelow, B. Treatment of anxiety disorders. Dialog-Clin. Neurosci. 2017, 19, 93-107. [CrossRef]

23. Vizard, T.; Davis, J.; White, E.; Beynon, B. Coronavirus and Depression in Adults, Great Britain. London. August 2020. Available online: https:/ / www.ons.gov.uk/peoplepopulationandcommunity/wellbeing/articles/coronavirusanddepressioninadultsgreatbritain/ june2020 (accessed on 4 March 2021).

24. American Psychiatric Association. What Is Depression? 2020. Available online: https://www.psychiatry.org/patients-families/ depression/what-is-depression (accessed on 4 March 2021).

25. Cuijpers, P.; Stringaris, A.; Wolpert, M. Treatment outcomes for depression: Challenges and opportunities. Lancet Psychiatry 2020, 7, 925-927. [CrossRef]

26. Cuijpers, P.; Cristea, I.A. What if a placebo effect explained all the activity of depression treatments? World Psychiatry 2015, 14, 310-311. [CrossRef] [PubMed]

27. British Medical Association. The Impact of COVID-19 on Mental Health in England; Supporting Services to Go beyond Parity of Esteem. London. 2020. Available online: https:/ / www.bma.org.uk/media/2750/bma-the-impact-of-covid-19-on-mentalhealth-in-england.pdf (accessed on 4 March 2021).

28. Weiner, L.; Berna, F.; Nourry, N.; Severac, F.; Vidailhet, P.; Mengin, A.C. Efficacy of an online cognitive behavioral therapy program developed for healthcare workers during the COVID-19 pandemic: The REduction of STress (REST) study protocol for a randomized controlled trial. Trials 2020, 21, 870. [CrossRef] [PubMed]

29. Eyre, H.A.; Ellsworth, W.; Fu, E.; Manji, H.K.; Berk, M. Responsible innovation in technology for mental health care. Lancet Psychiatry 2020, 7, 728-730. [CrossRef]

30. Barton, J.; Hine, R.; Pretty, J. The health benefits of walking in greenspaces of high natural and heritage value. J. Integr. Environ. Sci. 2009, 6, 261-278. [CrossRef]

31. Song, C.; Ikei, H.; Kagawa, T.; Miyazaki, Y. Effects of Walking in a Forest on Young Women. Int. J. Environ. Res. Public Health 2019, 16, 229. [CrossRef] [PubMed]

32. Lesser, I.A.; Prystupa, J.; Belanger, L.; Thomson, C.; Nienhuis, C.P. A mixed-methods evaluation of a group based trail walking program to reduce anxiety in cancer survivors. Appl. Cancer Res. 2020, 40, 1-10. [CrossRef]

33. Hassan, A.; Tao, J.; Li, G.; Jiang, M.; Aii, L.; Zhihui, J.; Zongfang, L.; Qibing, C. Effects of Walking in Bamboo Forest and City Environments on Brainwave Activity in Young Adults. Evid.-Based Complement. Altern. Med. 2018, 2018, 1-9. [CrossRef] [PubMed]

34. Natural England. 'Nature Nearby': Accessible Natural Greenspace Guidance. London. 2010. Available online: http://www. ukmaburbanforum.co.uk/docunents/other/nature_nearby.pdf (accessed on 4 March 2021).

35. World Health Organization. Urban Green Spaces: A Brief for Action. Copenhagen. 2017. Available online: https://www.euro. who.int/_data/assets/pdf_file/0010/342289/Urban-Green-Spaces_EN_WHO_web3.pdf\%3Fua=1 (accessed on 4 March 2021).

36. Moher, D.; Liberati, A.; Tetzlaff, J.; Altman, D.G. The PRISMA Group. Preferred reporting items for systematic reviews and meta-analyses: The PRISMA statement. PLoS Med. 2009, 6, e1000097. [CrossRef]

37. Klassen, T.P.; Jadad, A.R.; Moher, D. Guides for Reading and Interpreting Systematic Reviews. Arch. Pediatr. Adolesc. Med. 1998, 152, 700-704. [CrossRef]

38. Boland, A.; Cherry, G.; Dickson, R. Doing a Systematic Review: A Student's Guide; Sage: London, UK, 2013.

39. Sackett, D.L.; Straus, S.; Richardson, S.; Rosenbert, W.; Haynes, R. Evidence-Based Medicine: How to Practice and Teach EBM, 2nd ed.; Churchill Livingstone: London, UK, 2000.

40. Rojon, C.; McDowall, A.; Saunders, M.N.K. On the Experience of Conducting a Systematic Review in Industrial, Work, and Organizational Psychology. J. Pers. Psychol. 2011, 10, 133-138. [CrossRef]

41. Callahan, J.L. Constructing a Manuscript: Distinguishing Integrative Literature Reviews and Conceptual and Theory Articles. Hum. Resour. Dev. Rev. 2010, 9, 300-304. [CrossRef]

42. Cooper, C.; Booth, A.; Varley-Campbell, J.; Britten, N.; Garside, R. Defining the process to literature searching in systematic reviews: A literature review of guidance and supporting studies. BMC Med. Res. Methodol. 2018, 18, 85. [CrossRef]

43. Barnes, M.R.; Donahue, M.L.; Keeler, B.L.; Shorb, C.M.; Mohtadi, T.Z.; Shelby, L.J. Characterizing Nature and Participant Experience in Studies of Nature Exposure for Positive Mental Health: An Integrative Review. Front. Psychol. $2019,9,2617$. [CrossRef] 
44. Shuda, Q.; Bougoulias, M.E.; Kass, R. Effect of nature exposure on perceived and physiologic stress: A systematic review. Complement. Ther. Med. 2020, 53, 102514. [CrossRef]

45. Sturt, J.; Ali, S.; Robertson, W.; Metcalfe, D.; Grove, A.; Bourne, C.; Bridle, C. Neurolinguistic programming: A systematic review of the effects on health outcomes. Br. J. Gen. Pr. 2012, 62, e757-e764. [CrossRef] [PubMed]

46. Wells, G.A.; Shea, B.; O'Connell, D.; Peterson, J.; Welch, V.; Losos, M.; Tugwell, P. The Newcastle-Ottawa Scale (NOS) for Assessing the Quality of Nonrandomised Studies in Meta-Analyses. 2000. Available online: http://www.ohri.ca/programs/clinical_ epidemiology / oxford.asp (accessed on 17 March 2020).

47. Janeczko, E.; Bielinis, E.; Wójcik, R.; Woźnicka, M.; Kędziora, W.; Łukowski, A.; Elsadek, M.; Szyc, K.; Janeczko, K. When Urban Environment Is Restorative: The Effect of Walking in Suburbs and Forests on Psychological and Physiological Relaxation of Young Polish Adults. Forests 2020, 11, 591. [CrossRef]

48. Koselka, E.P.; Weidner, L.C.; Minasov, A.; Berman, M.G.; Leonard, W.R.; Santoso, M.V.; De Brito, J.N.; Pope, Z.C.; Pereira, M.A.; Horton, T.H. Walking Green: Developing an Evidence Base for Nature Prescriptions. Int. J. Environ. Res. Public Health 2019, 16, 4338. [CrossRef]

49. Song, C.; Ikei, H.; Park, B.-J.; Lee, J.; Kagawa, T.; Miyazaki, Y. Psychological Benefits of Walking through Forest Areas. Int. J. Environ. Res. Public Health 2018, 15, 2804. [CrossRef] [PubMed]

50. Korpela, K.M.; Stengård, E.; Jussila, P. Nature Walks as a Part of Therapeutic Intervention for Depression. Ecopsychology 2016, 8, 8-15. [CrossRef]

51. Bratman, G.N.; Daily, G.C.; Levy, B.J.; Gross, J.J. The benefits of nature experience: Improved affect and cognition. Landsc. Urban Plan. 2015, 138, 41-50. [CrossRef]

52. Song, C.; Ikei, H.; Kobayashi, M.; Miura, T.; Taue, M.; Kagawa, T.; Li, Q.; Kumeda, S.; Imai, M.; Miyazaki, Y. Effect of Forest Walking on Autonomic Nervous System Activity in Middle-Aged Hypertensive Individuals: A Pilot Study. Int. J. Environ. Res. Public Health 2015, 12, 2687-2699. [CrossRef]

53. Song, C.; Ikei, H.; Igarashi, M.; Takagaki, M.; Miyazaki, Y. Physiological and Psychological Effects of a Walk in Urban Parks in Fall. Int. J. Environ. Res. Public Health 2015, 12, 14216-14228. [CrossRef]

54. Marselle, M.R.; Irvine, K.N.; Warber, S.L. Examining group walks in nature and multiple aspects of well-being: A large-scale study. Ecopsychology 2014, 6, 134-147.

55. Song, C.; Joung, D.; Ikei, H.; Igarashi, M.; Aga, M.; Park, B.-J.; Miwa, M.; Takagaki, M.; Miyazaki, Y. Physiological and psychological effects of walking on young males in urban parks in winter. J. Physiol. Anthr. 2013, 32, 1-5. [CrossRef] [PubMed]

56. Hartig, T.; Mitchell, R.; De Vries, S.; Frumkin, H. Nature and Health. Annu. Rev. Public Health 2014, 35, 207-228. [CrossRef] [PubMed]

57. Capaldi, C.A.; Passmore, H.-A.; Nisbet, E.K.; Zelenski, J.M.; Dopko, R.L. Flourishing in nature: A review of the benefits of connecting with nature and its application as a wellbeing intervention. Int. J. Wellbeing 2015, 5, 1-16. [CrossRef]

58. Twohig-Bennett, C.; Jones, A. The health benefits of the great outdoors: A systematic review and meta-analysis of greenspace exposure and health outcomes. Environ. Res. 2018, 166, 628-637. [CrossRef]

59. Ogilvie, D.; Foster, C.E.; Rothnie, H.; Cavill, N.; Hamilton, V.; Fitzsimons, C.F.; Mutrie, N. Interventions to promote walking: Systematic review. BMJ 2007, 334, 1204-1207. [CrossRef] [PubMed]

60. Lee, I.-M.; Buchner, D.M. The Importance of Walking to Public Health. Med. Sci. Sports Exerc. 2008, 40 (Suppl. 1), S512-S518. [CrossRef]

61. Robertson, R.; Robertson, A.; Jepson, R.; Maxwell, M. Walking for depression or depressive symptoms: A systematic review and meta-analysis. Ment. Health Phys. Act. 2012, 5, 66-75. [CrossRef]

62. Kelly, P.; Williamson, C.; Niven, A.G.; Hunter, R.; Mutrie, N.; Richards, J. Walking on sunshine: Scoping review of the evidence for walking and mental health. Br. J. Sports Med. 2018, 52, 800-806. [CrossRef]

63. Kotera, Y.; Richardson, M.; Sheffield, D. Effects of Shinrin-Yoku (Forest Bathing) and Nature Therapy on Mental Health: A Systematic Review and Meta-analysis. Int. J. Ment. Health Addict. 2020, 1-25. [CrossRef]

64. Li, Q. Effect of forest bathing trips on human immune function. Environ. Health Prev. Med. 2009, 15, 9-17. [CrossRef] [PubMed]

65. Li, Q.; Kobayashi, M.; Wakayama, Y.; Inagaki, H.; Katsumata, M.; Hirata, Y.; Hirata, K.; Shimizu, T.; Kawada, T.; Park, B.; et al. Effect of Phytoncide from Trees on Human Natural Killer Cell Function. Int. J. Immunopathol. Pharmacol. $2009,22,951-959$. [CrossRef] [PubMed]

66. Cheng, W.-W.; Lin, C.-T.; Chu, F.-H.; Chang, S.-T.; Wang, S.-Y. Neuropharmacological activities of phytoncide released from Cryptomeria japonica. J. Wood Sci. 2009, 55, 27-31. [CrossRef]

67. Asmundson, G.J.G.; Fetzner, M.G.; DeBoer, L.B.; Powers, M.B.; Otto, M.W.; Smits, J.A.J. Let's Get Physical: A Contemporary Review Of The Anxiolytic Effects Of Exercise For Anxiety And Its Disorders. Depress. Anxiety 2013, 30, 362-373. [CrossRef] [PubMed]

68. Jayakody, K.; Gunadasa, S.; Hosker, C. Exercise for anxiety disorders: Systematic review. Br. J. Sports Med. 2014, 48, 187-196. [CrossRef]

69. Stonerock, G.L.; Hoffman, B.M.; Smith, P.J.; Blumenthal, J.A. Exercise as Treatment for Anxiety: Systematic Review and Analysis. Ann. Behav. Med. 2015, 46, 542-556. [CrossRef]

70. Rethorst, C.D.; Wipfli, B.M.; Landers, D.M. The Antidepressive Effects of Exercise. Sports Med. 2009, 39, 491-511. [CrossRef] 
71. Stanton, R.; Reaburn, P. Exercise and the treatment of depression: A review of the exercise program variables. J. Sci. Med. Sport 2014, 17, 177-182. [CrossRef]

72. Wolch, J.R.; Byrne, J.; Newell, J.P. Urban green space, public health, and environmental justice: The challenge of making cities 'just green enough'. Landsc. Urban Plan. 2014, 125, 234-244. [CrossRef]

73. Mears, M.; Brindley, P.; Maheswaran, R.; Jorgensen, A. Understanding the socioeconomic equity of publicly accessible greenspace distribution: The example of Sheffield, UK. Geoforum 2019, 103, 126-137. [CrossRef]

74. Lee, A.C.K.; Maheswaran, R. The health benefits of urban green spaces: A review of the evidence. J. Public Health 2011, 33, 212-222. [CrossRef] [PubMed]

75. Britton, E.; Kindermann, G.; Domegan, C.; Carlin, C. Blue care: A systematic review of blue space interventions for health and wellbeing. Health Promot. Int. 2020, 35, 50-69. [CrossRef] [PubMed]

76. Hoyle, H.; Hitchmough, J.; Jorgensen, A. All about the 'wow factor'? The relationships between aesthetics, restorative effect and perceived biodiversity in designed urban planting. Landsc. Urban Plan. 2017, 164, 109-123. [CrossRef]

77. Harris, V.; Kendal, D.; Hahs, A.K.; Threlfall, C.G. Green space context and vegetation complexity shape people's preferences for urban public parks and residential gardens. Landsc. Res. 2017, 43, 150-162. [CrossRef]

78. Kendal, D.; Williams, K.J.; Williams, N.S. Plant traits link people's plant preferences to the composition of their gardens. Landsc. Urban Plan. 2012, 105, 34-42. [CrossRef]

79. Southon, G.E.; Jorgensen, A.; Dunnett, N.; Hoyle, H.; Evans, K.L. Biodiverse perennial meadows have aesthetic value and increase residents' perceptions of site quality in urban green-space. Landsc. Urban Plan. 2017, 158, 105-118. [CrossRef]

80. Pett, T.J.; Shwartz, A.; Irvine, K.N.; Dallimer, M.; Davies, Z.G. Unpacking the People-Biodiversity Paradox: A Conceptual Framework. BioScience 2016, 66, 576-583. [CrossRef]

81. Cameron, R.W.F.; Brindley, P.; Mears, M.; McEwan, K.; Ferguson, F.; Sheffield, D.; Jorgensen, A.; Riley, J.; Goodrick, J.; Ballard, L.; et al. Where the wild things are! Do urban green spaces with greater avian biodiversity promote more positive emotions in humans? Urban Ecosyst. 2020, 23, 301-317. [CrossRef]

82. Wood, E.; Harsant, A.; Dallimer, M.; De Chavez, A.C.; McEachan, R.R.C.; Hassall, C. Not All Green Space Is Created Equal: Biodiversity Predicts Psychological Restorative Benefits from Urban Green Space. Front. Psychol. 2018, 9, 1-13. [CrossRef]

83. Van Heezik, Y.; Brymer, E. Nature as a Commodity: What's Good for Human Health Might Not Be Good for Ecosystem Health. Front. Psychol. 2018, 9, 1-5. [CrossRef] [PubMed]

84. Kobayashi, H.; Ikei, H.; Song, C.; Kagawa, T.; Miyazaki, Y. Comparing the impact of forest walking and forest viewing on psychological states. Urban For. Urban Green. 2021, 57, 126920. [CrossRef] 